\title{
CEEJ

\section{Pelatihan Program Statistic Product and Service Solution (SPSS) bagi Mahasiswa dan Dosen Sekolah Tinggi Ilmu Ekonomi H. Agus Salim Bukittinggi}

\author{
Hariman Syaleh* \\ Sekolah Tinggi Ilmu Ekonomi Haji Agus Salim Bukittinggi \\ harimansyaleh@yahoo.co.id
}

\begin{abstract}
Abstrak
Seiring berkembangnya teori dan metode dalam penyusunan karya ilmiah baik jurnal, skripsi, penelitian, tesis dan disertasi, saat ini sudah banyak metode yang dapat digunakan dalam penyelesaian metode-metode tersebut yang sebelumnya diselesaikan dengan program microsoft excel dan statistik yang membutuhkan waktu yang sangat lama, dengan adanya pelatihan ini diharapkan mahasiswa dan dosen dapat lebih mudah dalam menyelesaikan msalahnya baik dalam penulisan karya ilmiah, jurnal, skripsi, penelitian, tesis dan disertasi. Pemahaman konsep akan tercapai bila mahasiswa dan dosen diberi kesempatan untuk memperaktekkan bagaimana cara mengolah data mentah dengan program Statistic Product and Service Solution (SPSS) serta bagaimana cara meng analisa hasil output berupa angka-angka dan juga grafik sehingga diperoleh kesimpulan yang baik dan dapat memberikan kebijakan dan masukan bagi tempat penelitian. Mahasiswa dan dosen masih mengalami kesulitan dalam melakukan penelitian karya ilmiah baik jurnal, skripsi, penelitian, tesis dan disertasi karena kurangnya pemahaman di bidang program SPSS ini. Berkaitan dengan masalah tersebut, maka dilaksanakan sosialisasi serta pelatihan kepada mahasiswa dan dosen di Sekolah Tinggi Ilmu Ekonomi Haji Agus Salim Bukittinggi yang tergabung dalam Yayasan Indonesia Raya. Selama kegiatan para mahasiswa dan dosen sangat tertarik dan antusias memahami dan memperaktekkan program SPSS ini sebagai solusi atas permasalahan dibidang karya ilmiah baik jurnal, skripsi, penelitian, tesis dan disertasi yang selama ini dialami.
\end{abstract}

Keywords: jurnal, skripsi, tesis, disertasi, SPSS

\section{Pendahuluan}

Program Statistic Product and Service Solution (SPSS) merupakan salah satu program yang telah diajarkan pada mahasiswa di semester $\mathrm{V}$ tetapi bukan dengan program melainkan secara manual dengan belajar statistic, sehingga pemahaman mahasiswa di bidang Statistic Product and Service Solution (SPSS) masih minim atau dapat dikatakan nol karena berbeda dengan statistic yang dipelajari secara manual, sedangkan dengan program Statistic Product and Service Solution (SPSS) kita menggunakan perangkat computer dan cara kerjanya lebih mudah dan cepat untuk mendapatkan hasil output yang diharapkan. Seiring berkembangnya teori atau metode yang dikemukakan oleh beberapa ahli tentang metode-metode yang dipakai dalam penelitian, saat ini terjadi perubahan pula pada metode analisis data yang digunakan dengan program-program baik berupa Statistic Product and Service Solution (SPSS), Smart PLS atau dan juga SEM. Pelatihan program Statistic Product and Service Solution (SPSS) saat berupa peraktek cara pengolahan data mentah. Ketrampilan mahasiwa dan dosen memakai program Statistic Product and Service Solution (SPSS) tidak lagi hanya bertumpu pada latihan mencari hasil, namun juga sampai pada analisa hasil dan pemahaman. Tanpa pemahaman, para mahasiswa dan dosen dibidang program statistik produk and service solution (SPSS) mereka akan mengalamai kesulitan dalam mengikuti perkembangan alat 
metode yang dipakai dalam penelitian dan menyelesaikan persoalan-persoalan yang makin berkembang kedepannya.

Peningkatan mutu pendidikan dapat dicapai melalui berbagai cara, antara lain dengan meningkatkan kualitas mahasiswa dan dosen melalui pelatihan dan pendidikan. Peran mahasiswa dan dosen dalam proses pembelajaran di Indonesia saat ini masih sangat dominan meskipun dosen telah berupaya untuk menjadi fasilitator di samping sebagai sumber informasi. Disamping itu masih banyak juga mahasiswa dan dosen apabila melakukan penelitian atau penulisan tugas akhir berupa skripsi, tesis dan disertasi pada masalah kuantitatifnya di kerjakan sama orang-orang yang ahli program Statistic Product and Service Solution (SPSS) ini begitu juga denga skripsi kebanyakan mahasiswa menyerahkan skripsinya bagi orang-orang yang ahli di Statistic Product and Service Solution (SPSS) dengan mengeluarkan biaya yang tidak sedikit. Upaya meningkatkan kualitas mahasiswa dan dosen untuk menyelesaikan masalah-masalah yang dihadapi saat melakukan penelitian atau penulisan tugas akhir akan memberi banyak dampak positif, diantaranya tercapainya peningkatan kemampuan dalam menyelesaikan masalah penelitian dan penulisan tugas akhir serta peningkatan keprofesionalan dosen dan mahasiswa.

Berbagai upaya untuk meningkatkan profesionalitas mahasiswa dan dosen dapat dilakukan dengan meningkatkan pengetahuan dan pemahaman mengenai berbagai metode, pendekatan, serta strategi yang dapat diterapkan dalam penelitian dan penulisan tugas akhir untuk dapat memaksimalkan kemampuan dan pencapaian prestasi mahasiswa dan dosen. Pemilihan metode, pendekatan, maupun strategi yang tepat diharapkan dapat mengatasi masalah-masalah penelitian di lapangan, sehingga proses pendidikan dan pembelajaran yang inovatif dan hasil yang lebih baik, dapat diwujudkan secara sistematis.

Berdasarkan informasi dan diskusi yang dilakukan, sebagian besar mahasiswa dan dosen di Sekolah Tinggi Ilmu Ekonomi Haji Agus Salim Bukittinggi mengalami kesulitan dalam mengolahan data atau penggunaan program Statistic Product and Service Solution (SPSS) ini karena kurangnya pelatihan dan pemahaman mahasiswa dan dosen. Para mahasiswa dan dosen memiliki keinginan besar untuk dapat mengatasi masalah kesulitan dalam penelitian dan penulisan tugas akhir ini. Berkaitan dengan masalah tersebut, para dosen dan mahasiswa sangat tertarik untuk meningkatkan dan mengembangkan kemampuan meneliti dan pengolahan data dengan program statistik produk and service solution (SPSS) yang aktif dan kreatif. Mereka tertarik untuk mempelajari lebih dalam mengenai pengoperasian program Statistic Product and Service Solution (SPSS) ini untuk dikemas dengan pendekatan konstrutivisme dengan tujuan untuk memberikan solusi atas permasalahan penelitian dan penulisan tugas akhir bagi mahasiswa dan dosen yang selama ini dirasa cukup sulit.

Hal tersebut sejalan dengan pendapat Hudojo (1988), bahwa proses pembelajaran yang baik dapat menjadikan mahasiwa dan dosen memperoleh pemahaman pengolahn data dengan program Statistic Product and Service Solution (SPSS) dengan baik pula, sehingga mahasiswa dan dosen dapat dengan mudah mempelajari selanjutnya. Salah satu pendekatan yang memberikan kesempatan kepada mahasiswa dan dosen untuk mengalami sendiri pemahaman yang diperolehnya adalah pendekatan konstruktivisme. Elliott (2000) berpendapat 
bahwa, "Constructivism is an approach to learning that holds that people actively construct their own knowledge, and that reality is determined by the experiences of the knower". Artinya Konstruktivisme adalah suatu pendekatan pembelajaran yang menyatakan bahwa orang secara aktif membangun pengetahuan mereka sendiri, dan kenyataan itu ditentukan oleh pengalaman-pengalaman dari yang tahu. Untuk memfasilitasi hal tersebut maka dilaksanakan sosialisasi serta pelatihan kepada mahasiswa dan dosen Sekolah Tinggi Ilmu Ekonomi Haji Agus Salim Bukittinggi dalam Yayasan Indonesia Raya yang ada di Bukittinggi tentang Pelatihan Program Statistic Product and Service Solution (SPSS) Bagi Mahasiswa dan Dosen Sekolah Tinggi Ilmu Ekonomi Haji Agus Salim Bukittinggi. Tujuan dari kegiatan pengabdian masyarakat ini adalah untuk memberikan informasi dan pengetahuan serta membekali para mahasiswa dan dosen tentang peulisan penelitian baik tugas akhir atauupun, memotivasi para mahasiswa dan dosen untuk menumbuh-kembangkan budaya akademik di lingkungan sekolah di kalangan pendidik sehingga tercipta sikap proaktif di dalam melakukan perbaikan mutu pendidikan dan penelitian secara berkelanjutan dengan melaksanakan kegiatan pelatihan ini, dan membantu mahasiswa dan dosen menyusun skripsi dan melakukan penelitian bagi dosen sesuai dengan permasalahan dan metode analisa data yang dipakai. Setelah terlaksananya kegiatan ini, diharapkan beberapa manfaat dapat diperoleh diantaranya para mahasiswa dan dosen memiliki pengetahuan dan keterampilan mengenai pengolahan data dengan Program Statistic Product and Service Solution (SPSS) dan para mahasiswa dapat dapat mengimplementasikan pelatihan ini pada waktu melakukan penelitian tugas akhir atau skripsi, sedangkan bagi dosen diharapkan dapat mengimplementasikan pelatihan ini pada waktu melakukan penelitian di lapangan atau pembuatan jurnal yang bersifat kuantitatif, dan juga penyelesaian penelitian untuk disertasi atau tesis yang memakai program Statistic Product and Service Solution (SPSS).

\section{Metode}

Khalayak sasaran pada kesempatan pengabdian masyarakat ini adalah para mahasiswa dan dosen pada Sekolah Tinggi Ilmu Ekonomi Haji Agus Salim Bukittinggi di bawah Yayasan Indonesia Raya yang ada di Kota Bukittinggi Sumatera Barat. Peserta yang hadir pada ke giatan pengabdian masyarakat ini berjumlah 23 orang yang merupakan Mahasiswa dan dosen yang berasal dari Sekolah Tinggi Ilmu Ekonomi Haji Agus Salim Bukittinggi di bawah Yayasan Indonesia Raya yang ada di Kota Bukittinggi Sumatera Barat.

Metode yang digunakan dalam kegiatan pengabdian ini adalah (1) Ceramah yang digunakan untuk memberikan informasi dan manfaat tentang pengoperasian program Statistic Product and Service Solution (SPSS), (2) Praktek, dilaksanakan untuk menunjukkan langkah-langkah melaksanakan pelatihan sekaligus dalam rangka menggunakan program Statistic Product and Service Solution (SPSS) di dalam computer, (3) Pemberian Tugas digunakan dimana para mahasiswa dan dosen diberi penugasan untuk membuat pengolahan data dengan program Statistic Product and Service Solution (SPSS) sekaligus dalam rangka mengimplementasikan hasil dari pelatihan ini. (4) Selanjutnya mahasiswa diminta untuk menganalisa hasil output dari program Statistic Product and Service Solution (SPSS). 
Realisasi pemecahan masalah yang telah dilaksanakan dalam kegiatan pengabdian dilakukan dengan langkah berikut.

1. Pelaksanaan pelatihan, pendampingan dan workshop: penyampaian materi mengenai Pelatihan program Statistic Product and Service Solution (SPSS). Model-model metode atau alat yang dipakai dalam pengolahan data dengan program. Selanjutnya diberikan pelatihan mengenai pengolahan data dengan data mentah yang sudah disediakan sebelumnya kemudian dilanjutkan dengan melakukan uji instrument terlebih dahulu sebelum dilakukan uji-uji lebih lanjut. Dalam kegiatan ini mahasiswa dan dosen secara individu diminta untuk mengidentifikasi berbagai permasalahan dan kesulitan dam menggunakan program Statistic Product and Service Solution (SPSS) yang dialaminya sesuai dengan metode atau alat analisa yang dipakai dalam penelitian atau penulisan tugas akhir. Kegiatan pelatihan, pendampingan dan workshop ini dilaksanakan pada tanggal 12 Oktober 2019 bertempat di labor Komputer Sekolah Tinggi Ilmu Ekonomi Haji Agus Salim Bukittinggi di bawah Yayasan Indonesia Raya yang ada di Kota Bukittinggi Sumatera Barat.

2. Sebagai tindak lanjut dari kegiatan pelatihan, pendampingan dan workshop ini selanjutnya setiap mahasiswa dan dosen peserta diminta untuk melakukan penelitian di lapangan yang di oleh datanya menggunakan program Statistik Produk and Service Solution (SPSS). Penelitian ini diselesaikan oleh masing-masing mahasiswa dan dosen peserta pelatihan secara individu, sebagai implementasi hasil pelatihan dan workshop Pelatihan Program Statistic Product and Service Solution (SPSS) Bagi Mahasiswa dan Dosen Sekolah Tinggi Ilmu Ekonomi Haji Agus Salim Bukittinggi.

Dalam melakukan penelitian kualitatif dan kuantitatif akan banyak ditemukan alat analisa yang dipakai dalam program Statistik Produk and Service Solution (SPSS) salah satunya adalah uni instrument penelitian yang terdiri dari uji validitas dan uji reliabilitas.

\section{Analisis Regresi Linear Berganda}

Analisis ini digunakan untuk mengetahui seberapa besar pengaruh variabel bebas yaitu: gaya kepemimpinan (X1), motivasi (X2), dan lingkungan kerja (X3) terhadap variabel terikatnya yaitu penegakan disiplin (Y) yang dinamakan sebagai Ordinary Last Square (OLS) (Ghozali, 2009).

\section{Koefisien Determinasi (R2)}

Koefisien determinasi $\left(\mathrm{R}^{2}\right)$ pada intinya mengukur seberapa jauh kemampuan model dalam menerangkan variasi variabel terikat (Ghozali, 2009). Nilai Koefisien determinasi adalah antara nol dan satu. Nilai $\mathrm{R}^{2}$ yang kecil berarti kemampuan variabel-variabel bebas dalam menjelaskan variasi variabel terikat amat terbatas. Begitu pula sebaliknya, nilai yang mendekati satu berarti variabel-variabel bebas memberikan hampir semua informasi yang dibutuhkan untuk memprediksi variasi variabel trikat.

\section{Pengujian Hipotesis}

\section{Uji F}

Uji ini digunakan untuk menguji keberartian pengaruh dari seluruh variabel independen secara bersama-sama terhadap variabel dependen. Pengujian ini pada dasarnya menunjukkan apakah semua variabel independen yang dimasukkan 
dalam model mempunyai pengaruh secara bersamasama terhadap variabel dependen. Setelah diperoleh perhitungan, kemudian $\mathrm{F}$ hitung dikonsultasikan dengan $\mathrm{F}$ tabel pada taraf signifikansi $5 \%$. Apabila harga $\mathrm{F}$ hitung $\geq$ harga $\mathrm{F}$ tabel berarti seluruh variabel independen secara bersama-sama berpengaruh signifikan terhadap variabel dependen. Apabila Fhitung < Ftabel berarti seluruh variabel independen secara bersama-sama tidak berpengaruh signifikan terhadap variabel dependen (Ghozali, 2013).

\section{Uji t}

Menguji koefisien garis regresi digunakan uji statistik t. Uji t dilakukan untuk menguji signifikansi konstanta tiap variabel independen akan berpengaruh terhadap variabel dependen. Uji keberartian koefisien (bi) dilakukan dengan statistik-t. Hal ini digunakan untuk menguji koefisien regresi secara parsial dari variabel independennya. Uji statistik t pada dasarnya menunjukan seberapa jauh pengaruh variabel independen secara individual dalam menerangkan variasi variabel dependen. Dalam mengambil keputusan dilakukan dengan membandingkan nilai antara $t$ hitung dan $t$ tabel dengan taraf sinifikansi $5 \%$. Apabila nilai statistik $\mathrm{t}$ lebih tinggi dibandingkan nilai $\mathrm{t}$ tabel, maka variabel independen secara individual memiliki pengaruh yang signifikan terhadap variabel dependen (Ghozali, 2013).

\section{Hasil dan Pembahasan}

Dasi hasil kegiatan pelatihan, pendampingan dan workshop ini yang dilaksanakan pada tanggal 2 November 2019 bertempat di labor Komputer Sekolah Tinggi Ilmu Ekonomi Haji Agus Salim Bukittinggi di bawah Yayasan Indonesia Raya yang ada di Kota Bukittinggi Sumatera Barat sangat membantu sekali bagi mahasiswa yang sedang menyusun tugas akhir atau skripsi sehingga memudahkan mereka menuangkannya kedalam tugas akhirnya yang biasanya dikerjakan oleh orangorang yang ahli dibidang Program Statistik Produk and Service Solution (SPSS) sekarang mahasiswa sudah bisa mengerjakan sendiri, dan kegiatan ini sangat membantu sekali bagi mereka karena dengan adanya pelatihan Program Statistik Produk and Service Solution (SPSS) ini mahasiswa dapat lebih cepat dari biasanya dalam penyusunan tugas akhirnya karena biasanya kendala yang sering di dapatkan dilapangan adalah kesulitan mahasiswa dalam pengolahan data kuantitatif ini dengan Program Statistik Produk and Service Solution (SPSS) dan tidak banyak orang yang bias mengerjakannya sehingga memperlambat penulisan tugas akhirnya.

Kemudian dilihat dari dosen yang mengikuti pelatihan ini dapat lebih mudah dalam melakukan penelitian dan lebih mudah dalam penulisan tesis atau disertasinya, karena pada umumnya tesis atau disertasi selalu memakai analisis kualitatif dan kuantitatif yang dikerjakan memakai Program Statistik Produk and Service Solution (SPSS), karena secara otodidat di pelajari sangat sulit sekali jarang sekali orang yang bias belajar Program Statistik Produk and Service Solution (SPSS) secara otodidat kecuali di pelajari denga peraktek langsung. Kemudian bagi dosen yang sudah sertifikasi diwajibkan memiliki hasil penelitian minimal 2 dalam sati tahun, dan biasanya penelitian berupa jurnal ini memakai metode analisa kualitatif dan kuantitatif dengan memakai Program Statistik Produk and Service Solution 
(SPSS) untuk memperoleh hasilnya kemudian di analisa untuk memperoleh informasi yang diharapkan dari hasil penelitian ini.

Peserta yang hadir pada kegiatan pengabdian masyarakat ini sebanyak 23 mahasiswa dan dosen Sekolah Tinggi Ilmu Ekonomi Haji Agus Salim Bukittinggi di bawah Yayasan Indonesia Raya yang ada di Kota Bukittinggi Sumatera Barat. Kegiatan pengabdian kepada masyarakat ini dilaksanakan dalam 1 kali pertemuan satu hari penuh yang dilaksanakan pada hari sabtu pada tanggal 12 Oktober 2019. Dalam kegiatan pertemuan ini akan dibahas mulai dari cara penginstalan Program Statistik Produk and Service Solution (SPSS) ke dalam computer, kemudian menjelaskan semua aplikasi yang ada di dalam Program Statistik Produk and Service Solution (SPSS) dan kegunaan nya, setelah mahasiswa tahu dan faham terhadap semua aplikasi yang tersedia di dalam Program Statistik Produk and Service Solution (SPSS) ini maka dilanjutkan bagaimana cara memasukkan data primer yang berasal dari kuesioner yang disebarkan di lapangan, kemudian data skunder yang diperoleh dari perusahan di masukkan kedalam Program Statistik Produk and Service Solution (SPSS). Data tersebut akan kita masukkan kedalam program Statistik Produk and Service Solution (SPSS) dan kita gunakan untuk mencari regresi sederhana dengan cara melihat pengaruh variabel independen terhadap variabel dependen.

Tim pengabdi menyajikan materi ceramah berupa penjelasan mengenai seluk beluk hal-hal yang berkaitan dengan program Statistik Produk and Service Solution (SPSS) sehingga mahasiswa dan dosen mengerti dan faham tujuan di adakannya pelatihan ini. Pelaksanaan kegiatan pengabdian kepada masyarakat dilaksanakan dalam bentuk pelatihan, pendampingan dan workshop pelatihan program Statistic Product and Service Solution (SPSS) bagi mahasiswa dan dosen Sekolah Tinggi Ilmu Ekonomi Haji Agus Salim Bukittinggi. Selanjutnya diberikan penugasan pada para peserta untuk menginstal program Statistic Product and Service Solution (SPSS) di lettop masing -masing atau di dalam komputer yang sudah disediakan kampus sehingga kegiatan ini berjalan dengan lancar.

Pelaksanaan pendampingan pelatihan program Statistic Product and Service Solution (SPSS) bagi mahasiswa dan dosen Sekolah Tinggi Ilmu Ekonomi Haji Agus Salim Bukittinggi yang dilaksanakan pada tanggal 12 Oktober 2019. Peserta yang hadir dalam kegiatan pengabdian ini sejumlah 23 orang. Pada workshop pelatihan program Statistic Product and Service Solution (SPSS) bagi mahasiswa dan dosen Sekolah Tinggi Ilmu Ekonomi Haji Agus Salim Bukittinggi, ditampilkan dan disimulasikan contoh berupa data yang sudah disediakan pembicara dalam pelatihan ini kemudian langsung di peraktekkan di dalam komputer dan laptop masing-masing sesuai instruksi dari pembicara seperti terlihat pada gambar berikut ini : 

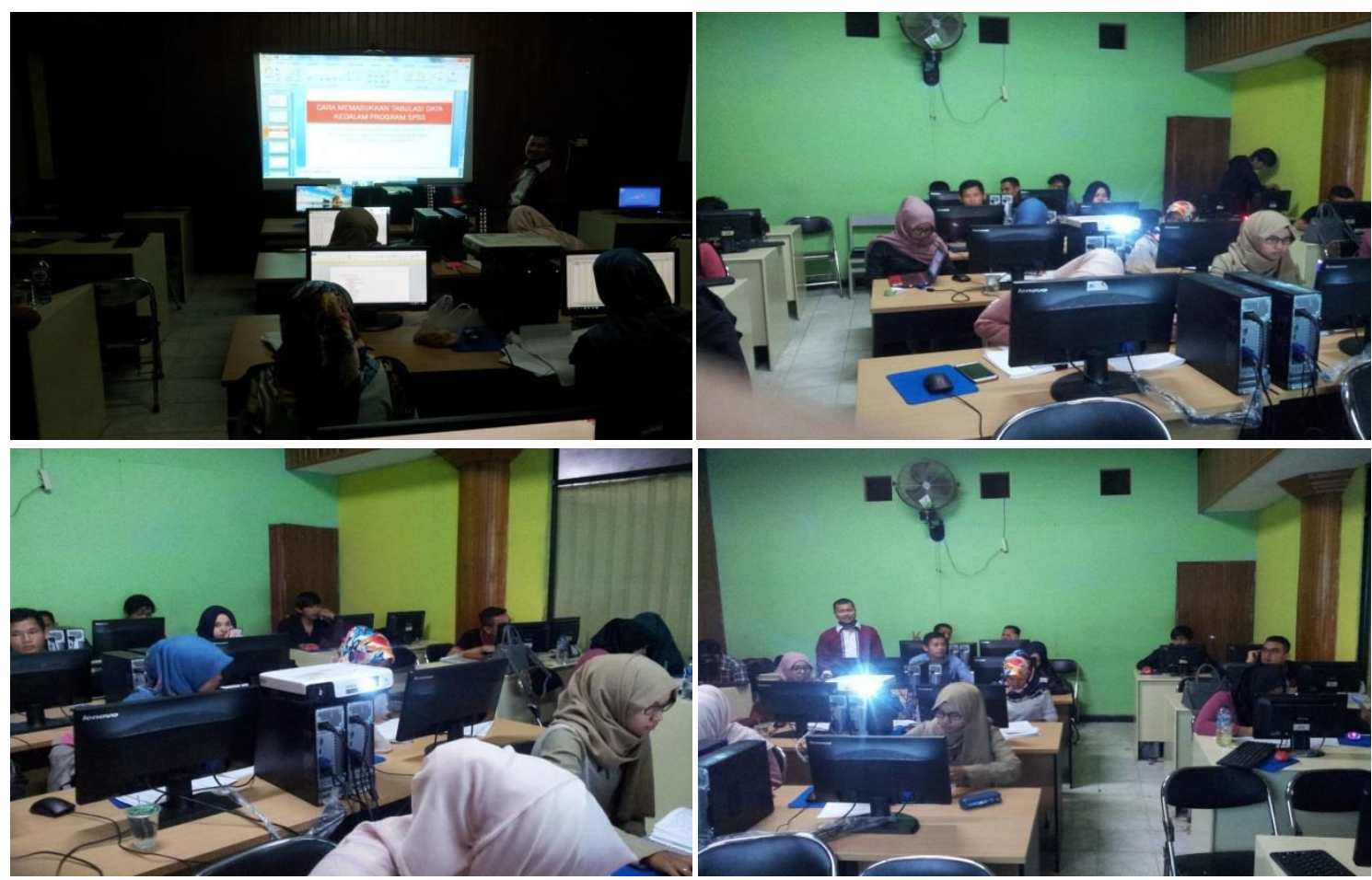

Sumber : Dokumentasi (2019)

Gambar 1. Suasana Kegiatan Pelatihan Berlangsung

Di akhir kegiatan seluruh peserta menyepakati bahwa jika dalam waktu ke depan diselenggarakan kegiatan semacam program ini mereka bersedia untuk mengikuti kembali, karena kebermanfaatan kegiatan ini. Secara umum pelaksanaan pengabdian sudah berjalan dengan baik, ada rencana tindak lanjut baik dari tim pengabdian secara terbuka mempersilahkan para peserta untuk menjalin komunikasi dengan narasumber. Pada tahap lanjut diharapkan peserta dapat mengaplikasikan mengenai pelatihan program Statistic Product and Service Solution (SPSS) serta dapat melaksanakan dan mengimplementasikan ilmu yang sudah di ajarkan baik dalam bentuk karya ilmiah berupa jurnal, tugas akhir, penelitian, tesis dan disertasi untuk kedepannya sehingga bermanfaat bagi pemateri dan anggota pelatihan.

\section{Simpulan}

Berdasarkan uraian laporan secara menyeluruh, dapat ditarik kesimpulan sebagai berikut:

(1) Strategi meningkatkan keterampilan mahasiswa dan dosen dibidang penelitian ini atau penyusunan tugas akhir di Sekolah Tinggi Ilmu Ekonomi Haji Agus Salim Bukittinggi dapat lebih baik kedepannya dan mengalami peningkatan dari tahun-tahun sebelumnya dibidang penelitian dan juga penulisan tugas akhir mahasiswa yang selalu mengalami kendala di dalam pengolahan data primer maupun scunder dengan program Statistic Product and Service Solution (SPSS). 
(2) Untuk menumbuhkembangkan budaya akademik di lingkungan perguruan tinggi di kalangan pendidik sehingga tercipta sikap proaktif di dalam melakukan perbaikan mutu pendidikan dan pembelajaran secara berkelanjutan dengan melaksanakan kegiatan pelatihan program Statistic Product and Service Solution (SPSS) bagi mahasiswa dan dosen di Sekolah Tinggi Ilmu Ekonomi Haji Agus Salim Bukittinggi maka perlu dilakukan kegiatan ini.

Untuk meningkatkan pemahaman para mahasiswa dan dosen dibidang program Statistic Product and Service Solution (SPSS) serta implementasinya dalam penulisan tugas akhir atau penelitian dilapangan yang berupa jurnal dan karya ilmiah lainnya. pelatihan program Statistic Product and Service Solution (SPSS) adalah memudahkan mahasiswa dan dosen dalam melakukan penelitian dibidang kuantitatif. Berdasarkan kegiatan sosialisasi yang telah dilaksanakan maka untuk kegiatan selanjutnya perlu adanya komunikasi antara perguruan tinggi dan narasumber dalam kegiatan pengabdian maupun kegiatan lainnya yang bertujuan untuk menyelesaikan masalah dibidang penelitian ini. Kegiatan ini masih perlu dilanjutkan dengan pendampingan, pelatihan dan motivasi pelaksanaan pengolahan data dengan program Statistic Product and Service Solution (SPSS) serta meng analisa hasil outputnya.

\section{Daftar Pustaka}

Elliot. 2000. Strategi Pembelajaran Kontemporer. Jurusan Pendidikan Matematika FMIPA Universitas Pendidikan Indonesia. Bandung.

Ghozali, Imam. 2009. Aplikasi Analisis Multivariate dengan Program SPSS. Badan Penerbit Universitas Diponegoro. Semarang.

Ghozali, Imam. 2013. Aplikasi Analisis Multivariate dengan Program IBM SPSS 21. Badan Penerbit Universitas Diponegoro. Semarang.

Hudojo, H. 1988. Mengajar Belajar. Proyek Pengembangan Lembaga Pendidikan Tenaga Kependidikan Dirjendikti. Jakarta.

Tim MGMP. 2005. Perangkat Pembelajaran. Tim MGMP Matematika SMP Kota Semarang. Semarang. 